\title{
Correlation between Levels of Serum Amylase, Lipase and Triglyceride in Acute Pancreatitis Patients
}

\author{
Gunalan Govindarajan ${ }^{1}$, Nina Tristina ${ }^{2}$ \\ ${ }^{1}$ Faculty of Medicine, Universitas Padjadjaran, ${ }^{2}$ Department of Clinical Pathology, Faculty of \\ Medicine, Universitas Padjadjaran/Dr. Hasan Sadikin General Hospital, Bandung
}

\begin{abstract}
Background: Acute pancreatitis is an inflammation of pancreas associated with reversible pancreatic parenchymal injury. Studies in several countries indicate that the levels of amylase and lipase are usually elevated among patients with acute pancreatitis. Furthermore, hyperlipidemia, mainly high levels of triglycerides, may present in acute pancreatitis. The aim of this study was to determine the levels of serum amylase and lipase as well as their correlation with serum triglyceride level in acute pancreatitis patients. Methods: A retrospective study was conducted on medical records of 48 acute pancreatitis patients in Dr. Hasan Sadikin General Hospital Bandung, Indonesia from 2007to 2011. Data collected from the medical records were age, sex, levels of serum amylase, lipase and triglyceride. The distribution of data was determined using Shapiro-Wilk test. The correlation between serum pancreatic enzyme and triglyceride was analyzed using Spearman-rank test.

Results: Most patients had increased levels of serum amylase and lipase in this study. However, no correlation between serum amylase and triglyceride ( $p$-value $=0.312$ ) was found. Furthermore, there was no correlation between serum lipase and triglyceride ( $\mathrm{p}$-value $=0.241$ ).

Conclusions: The levels of serum amylase and lipase increase in most patients with acute pancreatitis with no significant correlation between serum pancreatic enzymes (amylase and lipase) and triglyceride.
\end{abstract}

Key words: Acute pancreatitis, amylase, lipase, triglyceride.

\section{Introduction}

Pancreas is an accessory gland involved in digestion processes. ${ }^{1}$ Pancreas secretes multiple enzymes to digest protein, carbohydrate and fat rich foods. Enzyme that digests carbohydrate is pancreatic amylase. Pancreatic lipase, cholesterol esterase and phospholipase aid in digestion of fat. Meanwhile, the pancreatic enzymes involved in protein digestion are trypsin, chymotrypsin and carboxypolypeptidase. Besides, multiple digestive enzymes, pancreas also release hormones such as insulin, glucagon, somatostatin and pancreatic polypeptides. ${ }^{2}$

Pancreatitis is characterized by inflammation of the pancreas. This disease is classified into acute and chronic phase according to the course of injury to the pancreatic parenchyma. Acute pancreatitis is inflammation of pancreas associated with reversible pancreatic parenchymal injury. ${ }^{3}$

Acute pancreatitis is caused by several etiologic factors such as alcoholism, biliary tract diseases, metabolic disorders such as high triglyceride, genetic factors, mechanical factors or trauma, vascular disorders and infections. ${ }^{3}$ Triglycerides particularly which exceeds $1000 \mathrm{mg} / \mathrm{dL}$ also serves as a cause of acute pancreatitis..$^{4-9}$ Acute pancreatitis is usually diagnosed by history taking, physical examination, laboratory findings and imaging studies. ${ }^{10-12}$ Using laboratory measurement, measuring serum amylase and lipase levels can be useful for diagnosis. Usually, the levels of serum amylase and lipase will be elevated. ${ }^{10}$

There were some studies that indicated the association between acute pancreatitis and hyperlipidemia, in which there is an elevation in the level of triglyceride in acute pancreatitis patients..$^{5-9}$ In Bandung, this correlation study has not been assessed. The aim of this study is to perform an analytical study in determining

Correspondence: Gunalan Govindarajan, Faculty of Medicine, Universitas Padjadjaran, Jalan Raya Bandung-Sumedang Km.21, Jatinangor, Sumedang, Indonesia, Phone: +628179226451 Email: gunz290590@gmail.com 
Table 1 Characteristic of Acute Pancreatitis Patients

\begin{tabular}{ccccccc}
\hline & \multicolumn{7}{c}{ Gender } \\
\cline { 2 - 7 } Age (years) & \multicolumn{2}{c}{ Male } & \multicolumn{2}{c}{ Female } & \multicolumn{3}{c}{ Total } \\
\cline { 2 - 7 } & $\begin{array}{c}\text { Frequency } \\
\text { (n) }\end{array}$ & $\begin{array}{c}\text { Percentage } \\
\text { (\%) }\end{array}$ & $\begin{array}{c}\text { Frequency } \\
\text { (n) }\end{array}$ & $\begin{array}{c}\text { Percentage } \\
\text { (\%) }\end{array}$ & $\begin{array}{c}\text { Frequency } \\
\text { (n) }\end{array}$ & $\begin{array}{c}\text { Percentage } \\
\text { (\%) }\end{array}$ \\
\hline $1-10$ & 1 & 5.3 & 1 & 3.4 & 2 & 4.2 \\
$11-20$ & 0 & 0.0 & 3 & 10.3 & 3 & 6.2 \\
$21-30$ & 4 & 21.1 & 3 & 10.3 & 7 & 14.6 \\
$31-40$ & 2 & 10.5 & 4 & 13.8 & 6 & 12.5 \\
$41-50$ & 3 & 15.8 & 2 & 6.9 & 5 & 10.4 \\
$51-60$ & 6 & 31.6 & 12 & 41.4 & 18 & 37.5 \\
$61-70$ & 0 & 0.0 & 4 & 13.8 & 4 & 8.3 \\
$71-80$ & 3 & 15.8 & 0 & 0.0 & 3 & 6.2 \\
Total & 19 & 100.0 & 29 & 100.0 & 48 & 100.0 \\
\hline
\end{tabular}

the correlation between the levels of serum amylaseand lipase and triglyceride among patients diagnosed with acute pancreatitis in Dr. Hasan Sadikin General Hospital Bandung, Indonesia .

\section{Methods}

The research method used was analytical study using secondary data from medical records of patients diagnosed with acute pancreatitis in Dr. Hasan Sadikin General Hospital Bandung, Indonesia from 2007 to 2011.

The study was carried out with prior approval of Ethical Committee of Dr. Hasan Sadikin General Hospital Bandung. Only patients with complete medical record data of serum amylase, lipase and triglyceride levels diagnosed with acute pancreatitis in Dr. Hasan Sadikin General Hospital Bandung, Indonesia from 2007 to 2011 were eligible for this study.

Data collected from the medical records were age, sex, levels of serum amylase, lipase and triglyceride. The distribution of data was determined using Shapiro-Wilk test. The correlation between serum pancreatic enzyme and triglyceride was analyzed using Spearman-rank test.

\section{Results}

There were total of 288 cases of acute pancreatitis reported from years 2007 to 2011. From those 288 cases, 88 medical records were lost. From the remaining 200 medical records of the patients, only 48 medical records (24\%) were used in this study because the remaining medical records have incomplete data. The baseline characteristics of acute pancreatitis patients showed that most patients were in the age group of 51-60 years old $(37.5 \%)$. Female patients presented with the disease more than males (60.4\%) (Table 1$)$.

The data of the levels of serum amylase and lipase were not normally distributed, with the levels of amylase (median $=211.50 \mathrm{U} / \mathrm{L}$, range 78-6978 U/L) and lipase (median=268.40 $\mathrm{U} / \mathrm{L}$, range $=20.7-6082.2 \mathrm{U} / \mathrm{L}$ ) (Table 2).

Further analysis showed that majority of patients elevated amylase level $(85.4 \%)$, lipase level (97.9\%), and tryglyceride level

Table 2 Levels of Amylase, Lipase and TG in Acute Pancreatitis Patients

\begin{tabular}{lccc}
\hline & Median & Minimum & Maximum \\
\hline Amylase & 211.50 & 78.0 & 6978.0 \\
Lipase & 268.40 & 20.7 & 6082.2 \\
TG & 167.00 & 47.0 & 370.0 \\
\hline
\end{tabular}


Table 3 Levels of Amylase, Lipase and TG in Acute Pancreatitis Patients

\begin{tabular}{lccc}
\hline & & Frequency (n) & Percentage (\%) \\
\hline \multirow{2}{*}{ Amylase } & Normal & 7 & 14.6 \\
& Abnormal & 41 & 85.4 \\
Lipase & Normal & 1 & 2.1 \\
& Abnormal & 47 & 97.9 \\
TG & Normal & 19 & 39.6 \\
& Abnormal & 29 & 60.4 \\
\hline
\end{tabular}

Table 4 Correlation between Amylase and Lipase toward TG

\begin{tabular}{cccc}
\hline & & Amylase & Lipase \\
\hline \multirow{4}{*}{$\mathrm{TG}$} & $\mathrm{r}$ & -0.149 & 0.173 \\
& $\mathrm{p}$ & 0.312 & 0.241 \\
& $\mathrm{~N}$ & 48 & 48 \\
\hline
\end{tabular}

(60.4\%)(Table 3). However, serum amylase and lipase had no correlation with serum triglyceride (Table 4).

\section{Discussions}

Acute pancreatitis is an inflammatory process of pancreas mainly caused by alcoholism in western countries, in which may be correlated with the results of some studies that showed that most of the patients are males. ${ }^{13}$ In our study, females are higher in number than males who are diagnosed with acute pancreatitis, however, with no statistically significant. This difference may be due to frequency of alcohol addiction among men in this country is not as severe as in western countries, which contributes to less male patients in this local setting.

This disease also seems to be more common in patients above 40 years old. Based on several studies conducted worldwide, this result is mainly due to the nature of etiology of acute pancreatitis. The common etiologic factor which is biliary tract diseases is more common in adults over 40 years old with high incidence in people in the age group of 51-60 years old. ${ }^{14}$

In this study, amylase and lipase level are increased in majority of patients. This result supports most of the studies conducted on acute pancreatitis. The high levels of serum amylase and lipase are caused by inflammation of pancreas and excessive exocytosis of pancreatic enzymes. ${ }^{10,15}$

Acute pancreatitis is associated with high levels of serum triglycerides which is more than $1000 \mathrm{mg} / \mathrm{dL}$. This is mainly because high levels of triglycerides will tend to cause acute pancreatitis by two mechanisms. One of the mechanisms is by causing atherosclerosis in the blood vessels supplying the pancreas thus, leading to acute pancreatitis. The other mechanism is by increasing the activity of lipolytic lipase activity. ${ }^{5-8}$ Based on the analysis of the data obtained in this study, there are no correlation among serum triglyceride with serum amylase and lipase because most of the patients have serum triglyceride level less than $400 \mathrm{mg} / \mathrm{dL}$.

\section{References}

1. Moore KL, Dalley AF, Agur AMR. Clinically oriented anatomy. 6th ed. London: Lippincott Williams \& Wilkins; 2009.

2. Hall JE, Guyton AC. Guyton \& Hall physiology review. 11th ed. Philadelphia: Elsevier Saunders; 2006.

3. Kumar V, Abbas AK, Fausto N, Aster J. Robbins and Cotran Pathologic Basis of Disease, Professional Edition E-Book. Philadelphia: Expert Consult Online: Elsevier Health Sciences; 2009.

4. Wang GJ, Gao CF, Wei D, Wang C, Ding SQ. Acute pancreatitis: etiology and common pathogenesis. World J Gastroenterol. 2009;15(12):1427-30. 
5. Tonsi AF, Bacchion M, Crippa S, Malleo G, Bassi C. Acute pancreatitis at the beginning ofthe21stcentury: the state of theart.World J Gastroenterol. 2009;15(24):2945-59.

6. Pandol SJ, Saluja AK, Imrie CW, Banks PA. Acute pancreatitis: bench to the bedside. Gastroenterol. 2007;132(3):1127-51.

7. Yadav D, Pitchumoni CS. Issues in Hyperlipidemic Pancreatitis. J Clin Gastroenterol. 2003;36(1):54-62.

8. Ewald N, Hardt PD, Kloer H-U. Severe hypertriglyceridemia and pancreatitis: presentation and management. Curr Opin Lipidol. 2009;20(6):497-504.

9. Gan SI, Edwards AL, Symonds CJ, Beck PL. Hypertriglyceridemia-induced pancreatitis: a case-based review. World J Gastroenterol. 2006;12(44):7197-202.

10. Matull WR, Pereira SP, O'Donohue JW. Biochemical markers of acute pancreatitis. J Clin Pathol. 2006;59(4):340-4.
11. Kwon RS, Brugge WR. New advances in pancreatic imaging. Curr Opin Gastroenterol. 2005;21(5):561-7.

12. Whitcomb DC. Acute pancreatitis.N Engl J Med. 2006;354(20):2142-50.

13. Satoh K, Shimosegawa T, Masamune A, Hirota M, Kikuta K, Kihara Y, et al. Nationwide epidemiological survey of acute pancreatitis in Japan. Pancreas. 2011;40(4):503-7.

14. Shen H-N, Lu C-L, Li C-Y. Epidemiology of First-Attack Acute Pancreatitis in Taiwan From 2000 Through 2009: A Nationwide Population-Based Study. Pancreas. 2012;41(5):696-702.

15. McPherson RA, Pincus MR, Henry JB. Henry's clinical diagnosis and management by laboratory methods. 21st ed. Philadelphia: Saunders Elsevier; 2007. 